\title{
Learning in SME Internationalization: A New Perspective on Learning From Success versus Failure
}

\author{
Jeoung Yul Lee ${ }^{1,2}$. Alfredo Jiménez ${ }^{3}$ - Timothy M. Devinney ${ }^{4}$
}

Published online: 25 July 2020

(c) Springer-Verlag GmbH Germany, part of Springer Nature 2020

\begin{abstract}
Entrepreneurial small- and medium-sized enterprises (SMEs) play a significant role in nearly all economies and are responsible for a significant proportion of cross-border transactions. In order to create and capture opportunities across borders, entrepreneurs in SMEs rely heavily on both self- and vicarious- and experience-based organizational learning. Although a significant percentage of the academic literature has concerned itself with learning from successful experience (or general experience), learning from failed experience (or learning from success versus failure) has receive much less attention. This is despite the fact that failure is generally more pervasive, particular with respect to SMEs, than success. In this paper, we review the extant knowledge on SME success- and failure-based learning from internationalization, with particular emphasis on how the two bases of learning interact. In addition, we relate the five focused issue articles that build on and extend this literature into a set of insightful theoretical and managerial contributions.
\end{abstract}

Keywords Internationalization process · Learning in internationalization · Learning from success versus failure $\cdot$ Small and medium-sized enterprise (SME)

\section{Introduction}

It is well established that the process by which a firm internationalizes has important repercussions for the future success or failure of firms operating in those foreign markets (Qian et al. 2018; Sedziniauskiene et al. 2019). Because of the

Jeoung Yul Lee

jeoungyul@hongik.ac.kr

1 National Research Base of Intelligent Manufacturing Service, Chongqing Technology and Business University, Chongqing, China

2 School of Business Management, Hongik University, Sejong, South Korea

3 Department of Management, Kedge Business School, Talence, France

4 The Alliance Manchester Business School, The University of Manchester, Manchester, UK 
importance of internationalization process to internationalization outcomes, International Business (IB) scholars have embraced internationalization process as a cornerstone conceptual contribution to both the academic literature and with respect to the practical guidance the field gives to managers (Casillas and Moreno-Menendez 2014; Oehme and Bort 2015; Santangelo and Meyer 2011; Sui and Baum 2014).

At the core of the internationalization process literature is Johanson and Vahlne's (1977) Uppsala international process model, as well as well as a series of refinements and updates (Johanson and Vahlne 1990, 2003, 2006, 2009). In its original conceptualization, the Uppsala model, was very much deterministically structured in its prescriptions and predictions. However, by 2009, this rather rigid approached had changed, reflecting more fluidity with respect to "internationalization as an entrepreneurial process in a business network context" (Forsgren 2016, p. 1135). More recent work has added a more nuanced understanding of what is meant by a firm's internationalization process (Blankenburg Holm et al. 2015; Casillas and MorenoMenendez 2014; Oehme and Bort 2015; Santangelo and Meyer 2011; Schweizer et al. 2010; Sui and Baum 2014; Vahlne and Johanson 2013). This more recent work has not only put greater emphasis on the role of networks of various forms but also on the constitution and structure of these networks and what externalities flow into and from the firms that constitute them; having taken to heart Johanson and Vahlne's (2009) call for examination of the role of knowledge and learning as key output of the process of internationalization per se. As Forsgren (2016) notes, this consolidation of business network theory and entrepreneurship in the Uppsala model is crucial, as it demands fundamental consideration of the firm's cognitive enhancement via the internalization process with the consequent implications of a relationship between internationalization and entrepreneurship.

In this article and the focused issue of articles, we place attention on the topic of knowledge and learning of entrepreneurial firms in their internationalization process in line with Johanson and Vahlne's (2009) updated model. We expand on the exiting IB literature by concentrating not only on learning from success and general experience but learning from failure. We believe this trend toward learning from success or general experience is explained by both the limited data available regarding failure cases, as well as the tradition by which scholars follow previous research streams. Like Madsen and Desai (2010) we believe that "organizations learn more effectively from failures than successes that knowledge from failure depreciates more slowly than knowledge from success, and...the magnitude of failure influence how effectively organizations can learn from various forms of experience" (p. 451).

In the next section, we discuss the original and updated models of Johanson and Vahlne (1977, 2009) focusing on knowledge and learning in the internationalization process, with particular emphasis on the consequences for entrepreneurship. This is followed by a discussion about the entrepreneurship and the internationalization process model. We follow this with a review of nearly three decades of work on learning in SME internationalization and then discuss the prior literature on learning from failure. The goal, which we cover in the penultimate section, is a combination of the concept of learning in SME internationalization and 
the concept of learning from success and failure into a new model. Finally, we review the five papers in our focused issue and relate them to this new theoretical structure. We conclude with some implications for future research.

\section{Knowledge and Learning in The Uppsala Tradition}

Johanson and Vahlne's (2009) variant of the Uppsala model reflected a research trend in which firms' organizational learning and internationalization process contexts, concurrently, have rose to prominence when compared to the original Uppsala model of 1977. In its original form, the Uppsala model conceived of firm knowledge as sprouting from its current operational activities. In addition, there was also the implicit assumption that when the authors referred to 'knowledge', it meant solely market-based knowledge (Barkema et al. 1996; Erramilli 1991; Luo and Peng 1999; Petersen et al. 2003). This was expanded upon when Axelsson and Johanson (1992) introduced the role of business network in market-learning process. Since 1977, IB scholars have come to view general market knowledge and general internationalization knowledge as increasingly crucial to internationalization process, notably due to their influence on foreign market entry, acquisition, alliance, core business, and so on (Chang 1995; Hoang and Rothaermel 2005; Nadolska and Barkema 2007; Padmanabhan and Cho 1999; Sapienza et al. 2006). However, general internationalization knowledge can come not only from these forms of experiences and learning (in association with foreign market entry, acquisition, alliance, core business, etc.), but also from the various contexts and conditions existing in the heterogeneous markets in which firms are operating (Barkema and Vermeulen 1998).

Indeed, Johanson and Vahlne (2009) added the notion of 'relationship-specific knowledge' based on a linkage with the business network perspective. In their revised view, specific knowledge can be developed from partners' interactions, and this knowledge can nurture partners' resources and capabilities each other. This 'general relationship knowledge' reflects the interactive learning regarding how to coordinate the sets of learning and knowledge across heterogeneous overseas markets (Johanson and Vahlne 2003). This newly added 'relationship-specific knowledge' differs from the 1977 Uppsala definition of 'general market knowledge' in that this new form of knowledge comes from business networks-based interactions between buyers' user learning and sellers' producer learning.

Finally, it is important to note that the Uppsala model, in all its varieties, is not free of criticism. For example, the literature claimed that there are non-experiential learning types - i.e., acquisition, imitation, and search which can act as a trigger to accelerate the internationalization process (Forsgren 2002). Other scholars emphasize that the original Uppsala model is fundamentally deterministic, but, in reality, subnational managerial discretion is crucial in the internationalization process (Petersen et al. 2003). This is actually a critical fact for SMEs where ownership and management are generally overlapping or quite close. Johanson and Vahlne's (2009) counterargument is that that gradual experiential learning should be the fundamental mechanism to understand their business network view-based internationalization and its learning connotation after all. 


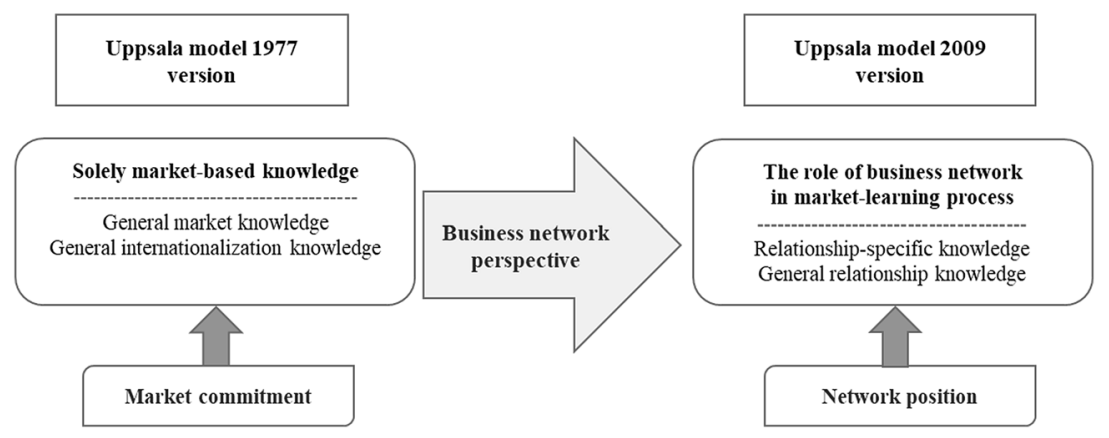

Fig. 1 The evolution of ideas in knowledge and learning in Uppsala models

Figure 1 shows the evolution of ideas in knowledge and learning in Uppsala models over time.

\section{Entrepreneurship and Internationalization Process Model}

In the 2009 version of the Uppsala model, Johanson and Vahlne combined entrepreneurship with a business network perspective. In particular, the revised model drew on Kirzner's (1973) conceptualization of entrepreneurship as a discovery of opportunities. Unlike Schumpeter's (1934) perspective that entrepreneurial chances are created by entrepreneurs, Johanson and Vahlne emphasize 'opportunity recognition' via the discovery of the unknown grounded in alertness and readiness (Schweizer et al. 2010).

Despite this confluence between the revised Uppsala model and Kirzner's conceptualization of entrepreneurship, it is also worth noting some important differences in the perspectives taken. Kirzner (2009, p. 145) argues that his view of entrepreneurship is completely different from entrepreneurial success, but more related to "the nature of the market process". Kirzner's fundamental claim is that entrepreneurship is the interaction among market opportunities, organizational resources, and overseas investments (Kirzner 1978). In contrast, the Uppsala model emphasizes that "knowledge of opportunities and problems" is critical "to initiate decisions" in the internationalization process (Johanson and Vahlne 2009, p. 1418), which depends on experiential learning, gradual process, and path dependency when it comes to knowledge and learning. Kirzner's focus on the composition of entrepreneurship is somewhat dissimilar from, though not holey alien to, the incremental logic of the Uppsala model (Foss and Klein 2012).

Nevertheless, there are also some alternatives views combining entrepreneurship with the Uppsala model. One of the most appealing alternatives is that building on Knight's (1921) perspective, which aligns entrepreneurship with a revised Uppsala model by incorporating some common themes: 
(1) Learning and experimentation inspires entrepreneurial activities;

(2) Entrepreneurial commitment can occur within organizations rather than independent of them;

(3) Entrepreneurial decision-making is a process rather than opportunity discovery;

(4) Overseas commitment is based on the risk based on an entrepreneurial judgement; and,

(5) Entrepreneurship is based on not only the entrepreneurs' expectations for the future, but also the organizations' existing resources and knowledge.

Indeed, if we take the view that entrepreneurship is a process of innovation based on experimental learning and knowledge, it is similar in most forms to an internationalization process by which firms enter into new markets thereby creating entrepreneurial opportunities and learning (Jones and Coviello 2005). Johanson and Vahlne (2009) also claimed that their perspective on internationalization process is similar to an entrepreneurial process; hence, it could be described as an example of corporate entrepreneurship. Yet, they claim their updated internationalization process model is very much about the "relationship development process" (Johanson and Vahlne 2009, p. 1419), which links their thinking to the relationship between entrepreneurial firms' knowledge/learning and network knowledge/learning. Although in the 2009 model Johanson and Vahlne explicitly described their combination with the entrepreneurship and business network views in terms of network knowledge/learning, network theorists have emphasized that the role of network knowledge and learning is critical not only for entrepreneurial learning but also for learning in the internationalization.

The 2009 version of the Uppsala model presents "a new perspective on internationalization more strongly than being a specific model of firm's internationalization" (Forgren 2016, p. 1142), and this new perspective is tightly knotted with entrepreneurial opportunities and learning (Jones and Coviello 2005), particularly in terms of the internationalization process. As such, the 2009 Uppsala model provides a fruitful beginning point for linking entrepreneurial opportunities to learning in SME internationalization process.

\section{Learning in SME Internationalization}

Learning in entrepreneurial firms' internationalization has been discussed and researched by IB and entrepreneurship scholars, based not only on the original and the updated Uppsala internationalization process model, but also based on the conception of the 'born global' firm. Building on the popular work of McKinsey dating from 1993, Knight and Cavusgil (2004) provided a more structured born global firm framework which describes young and entrepreneurial firms' early and rapid internationalization phenomenon within the context of existing IB theory. Focusing on born global exporters, Knight and Cavusgil integrated marketing, entrepreneurial and capability-building perspective regarding SMEs' exporting.

Back when the born global firm framework was released in the 1990s, early internationalization by exporting SMEs was a novel concept within the academic 
literature (outside organizations such as the German Mittelstand, which were studied heavily). However, the rise of technology-based SMEs, particularly in middle market economies, made the phenomenon one of both practical and academic interest. Yet, in their retrospective, Cavugil and Knight (2015, p. 3) claimed that "the issue of why some firms internationalize early, others late in their evolution, and still others choose to remain local, is a fundamental question for international business scholarship."

"International ventures" share the similar conception with the "born global firms", but there are some distinct differences. Oviatt and McDougall (1994, p. 49) explained that international ventures are entrepreneurial organizations that pursue internationalization in multiple markets leveraged by the competitiveness of "the use of resources and the sale of outputs" from their very beginning. International entrepreneurship ultimately has become the catch-all that incorporates born global firm and international ventures when scholars explain the phenomenon of early and rapid internationalization (Kiss et al. 2012; McDougall and Oviatt 2000; Smallbone et al. 2014).

Historically, the phenomenon of early exporting by young and entrepreneurial start-ups was a topic of interest and relevance in developed small market economics, such as Denmark and Australia, (Mort and Weerawardena 2006; Sullivan-Mort and Weerawardena 2006), where the domestic market didn't generate the scale necessary for success. However, the topic generated even more interest when it caught on in large market countries, such as the US (Knight and Liesch 2016), and, more recently, in both large (e.g., China and India) and small (e.g., Romania, Hungary) emerging economies (Deng et al. 2018; Eurofound 2012).

These born global firms or international small ventures are characterized by early and rapid internationalization even if they have relatively small scale and limited tangible resources and capabilities as their key to success is 'asset parsimony' (Cavugil and Knight 2015), meaning the minimization (or reduction) of assets utilized in making the product or providing the service (Miller 1998). From the perspective of entrepreneurs and their firms, born global firms' early and rapid internationalization is clearly contrary to Johanson and Vahlne's Uppsala model $(1977,2009)$, particularly in its original deterministic form. Further, due to the recent rise of digitalization, platforms, omni-channel market models and Industry 4.0, many smaller and less resourced start-ups have also achieved large levels of internationalization driven by rapid scalability and access to global venture capital and private equity financing (Bingham and Davis 2012; Bingham and Haleblian 2012; Deligianni et al. 2015; Gupta 1989; Monaghan et al. 2020; Oviatt and McDougall 1994; Rennie 1993; Sleuwaegen and Onkelinx 2014; Tuomisalo and Leppäaho 2019). But, as a number of scholars have shown, entrepreneurial firms' internationalization requires an innovation culture that generates knowledge acquisition leading to successful overseas performance based on their entrepreneurial learning (Gabrielsson et al. 2008; Weerawardena et al. 2007) that allows these firms to counter their lack of tangible and financial resources (Weerawardena et al. 2007).

There is strong evidence that the role of networks matters significantly, particularly in situations where the SME is only a small piece of the large global value 
chain structure (Cavusgil and Knight 2009; Chetty and Campbell-Hunt 2003; Schwens and Kabst 2009). In early and rapid internationalization, these start-ups benefit from their relationship network knowledge, network learning and social capital (Cavusgil and Knight 2009; Chetty and Campbell-Hunt 2003; Schwens and Kabst 2009). These can arise from learning from foreign partners, ubiquitous information and knowledge, efficient logistics knowledge, relationship-based knowledge absorption and so on (Cavugil and Knight 2015).

More recently, a variety of researchers have explored learning in SME internationalization since these early models and frameworks broke the ground of entrepreneurial internationalization and general internationalization process models. For example, based on institutional, network, and organizational learning theory, Oehme and Bort (2015, p. 629) examined "how a firm's network position as well as its experiential knowledge moderate imitative behavior in internationalization" with the sample of 977 German biotechnology SMEs during 1996-2012. Their view is in line with previous studies showing that international experience is critical for a successful internationalization process outcome (e.g., De Clercq et al. 2012).

When scholars have looked at young firms' early and rapid internationalization, they have usually relied on the knowledge-based view and/or organizational learning theory to investigate knowledge acquisitions and experiential learning (e.g., Bruneel et al. 2010; Casillas et al. 2015; Schwens and Kabst 2009). Both formal ties (Gabrielsson and Kirpalani 2004) and informal ones (Prashantham et al. 2015; Presutti et al. 2007) are significant to explain these entrepreneurial firms' knowledge and learning. Similarly, the role of networks has been emphasized to explain the relationship between internationalization and export intensity of international new ventures with knowledge and experiential learning (e.g., Casillas et al. 2015; Schwens and Kabst 2009; Zhou et al. 2007).

Learning in entrepreneurial firms' internationalization can be based on organizational learning arising from foreign commitment in overseas markets, entrepreneurial orientation, shared vision and identity, open-mindedness, creativity, internal and external trial and error process, etc. (Zahra et al. 2000; Zhou and Wu 2014). Innovative start-ups can evolve through knowledge development and learning leading to knowledge capability-building in their early internationalization in various foreign markets (Coviello 2015).

This organizational learning is associated with a longitudinal dynamic that relates to the success of SME internationalization as evidence exists that continuous commitment to internationalization is crucial for SMEs' learning from their internationalization. For example, Bruneel et al. (2010) showed young firms' organizational experiential learning can support the momentum when these firms perform internationalization to leverage them to expand their overseas sales. Focusing on experiential learning of young firms, Schwens and Kabst (2009) showed that the internationalization modes of early internationalizers are steady over a period of time. Their finding supports the notion that international ventures not only learn from their internationalization process, but also can develop routines that they can use repeatedly over time. This finding is consistent to organizational learning theory that there is a momentum to gain experiential learning by overcoming organizational inertial 
forces, and, in this way, organizations can change processes and routines so that they can use afterwards rely on their refinement and repetition (e.g., Beck et al. 2008).

Finally, other forms of organizational learning, "congenital learning" (learning by the management team's pre-new-venture international experience) and "vicarious learning" (learning by observing peers) can help international new ventures move more rapidly and successfully internationalize when compared to experiential learning with incremental internationalization alone (Pellegrino and McNaughton 2015, p. 457). Pellegrino and McNaughton (2015) claimed that in their early stages international ventures rely on congenital learning. However, as these ventures evolve and mature, they depend more on vicarious, searching, and noticing learning processes in their internationalization process. Finally, in their later stages, they become reliant on experiential learning.

This is in line with Li et al.'s (2004) argument that entrepreneurial firms are searching before their overseas foray by researching overseas markets, and with Yeoh (2004) and Fletcher and Harris (2012) who claim that smaller firms need to internationalize based on the absorption of product and technology knowledge and learning from internationalization by entering overseas markets.

In sum, learning in SME internationalization can be explained by Johanson and Vahlne's $(1977,2009)$ models, as well as a more structured born global firm framework (Knight and Cavusgil 2004). This learning in SME internationalization can include self-, congenital, and vicarious learning, as well as linking to learning from success and failure, which we will cover in Sect. 5.

\subsection{Learning in SME Internationalization: Bibliographic Evidence}

To capture more formally, the structure and evolution of academic research on learning in SME internationalization, we conducted a historical search of the literature, which is summarized in Table $1 .^{1}$

As can be seen in Table 1, the first two papers in IB to cover the topic of learning in SME internationalization were published in 1997. These two papers Coviello and Munro (1997) and Madsen and Servais (1997) reveal how the form of internationalization process of born global firms and knowledge-based small software firms differ from what is predicted by the 1977 Uppsala model. For example, Madsen and Servais (1997, p. 57), focus on "the founder characteristics and market conditions" of SMEs, a factor that had not been addressed by the 1977 Uppsala model, while both papers highlight the different learning processes and mechanisms of gaining market knowledge that differ greatly from what was proposed originally by Johanson and Vahlne.

However, it was not until 2001 until the topic rises once again. Minguzzi and Passaro (2001) claimed that 'entrepreneurial culture' and the 'learning processes' are present in the firm as reciprocal dependence mechanisms. This dependence arises because the entrepreneurial culture of SMEs evolves in relation to the capacity for

\footnotetext{
1 See the method and details of this literature search is in Appendix 1.
} 


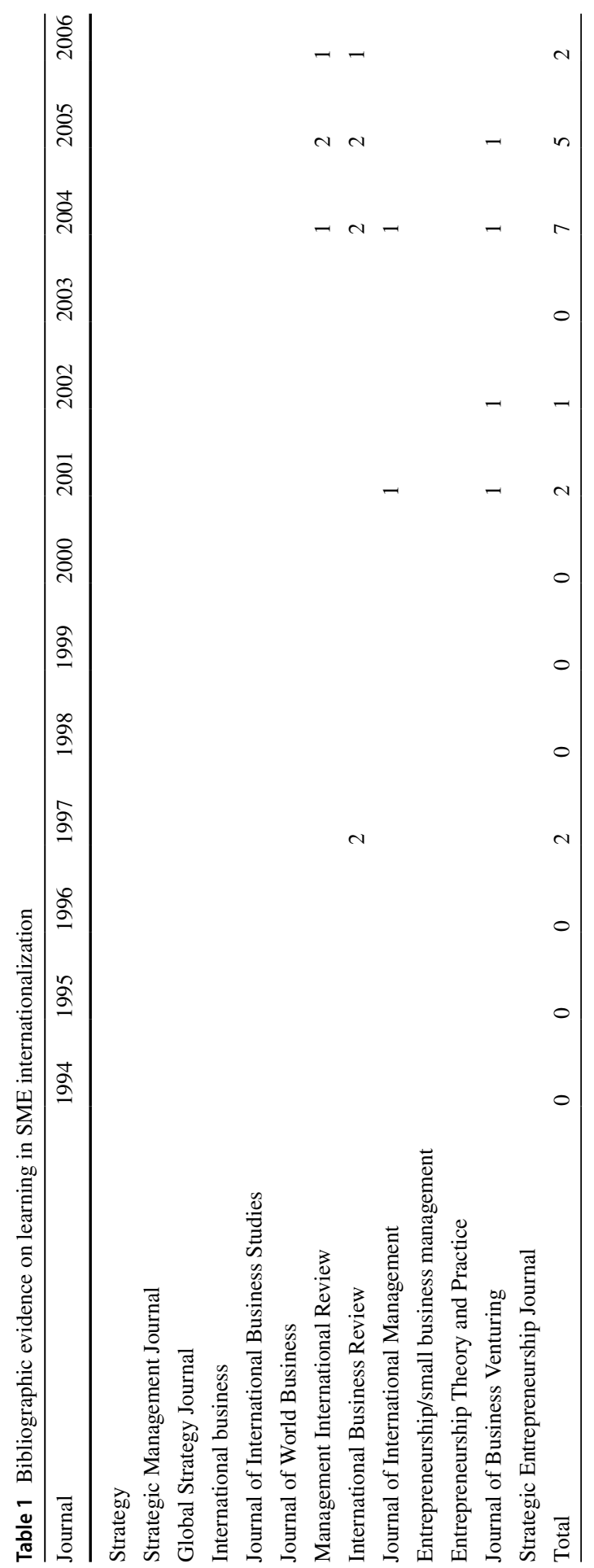




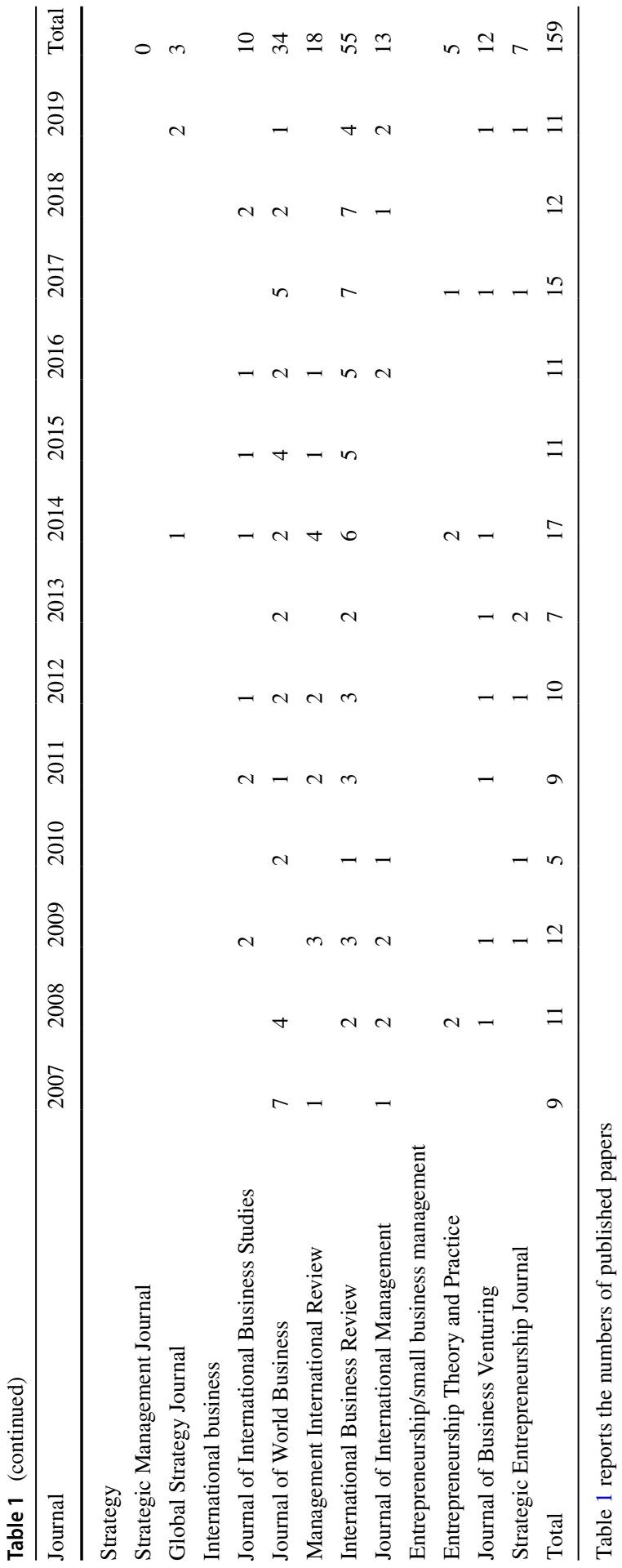


learning in these firms' internationalization. This was reinforced 3 years later in $\mathrm{Li}$ et al. (2004, p. 93), who argued that learning in SME internationalization process was "a hybrid model of experiential learning and planning".

Somewhat surprising is the paucity of work on the topic e.g., the "Journal of International Business Studies" had not covered the topic of learning and SME internationalization at all in the period 1994-2008 but 2009 brought two of the more influential articles published, Johanson and Vahlne (2009) and Knight and Kim (2009). We have already spoken of Johanson and Vahlne (2009) at length. Knight and Kim (2009, p. 256) add to the conversation with emphasize on IB competences in SME internationalization: "the superior ability of certain firms to create new knowledge leads to the development of organizational capabilities...consisting of critical competences and embedded routines".

In addition to this work, 2009 was something of the start of a wave or work on SME internationalization, with four journals publishing 10 papers regarding on the topic (with three in "Management International Review"). In 2011 and 2012, six journals published another 20 papers on the topic, while in 2014 we see the largest number of articles in a year to date, with 17 papers appearing, four of which were published by "Management International Review". Since that peak we have seen a steady stream of work on the topic, with consistent double-digit output in the various IB journals.

Overall, our literature search shows a consistent and steady supply of publications on the topic of learning in SME internationalization since 2007, but notably in the period from 2014 to 2019 . This result shows that this research area, while still developing, is meaningful nowadays.

\section{Learning From Failure}

Organizational learning is regarded as expectations and assumptions by organizational members who accumulate knowledge based on cause-and-effect linkages in their operational domains (Huber 1991). Organizational knowledge is separate and distinct from individual knowledge, and this difference enables an organization to hold onto this knowledge even when individuals leave the organization (De Holan and Phillips 2004; Eisenhardt and Martin 2000; Levitt and March 1988). Organizational knowledge is regarded as: (1) codified and procedural knowledge that resides in organizational routines and goals as well as operational procedures and norms; and (2) tacit knowledge that resides in collective cognitions (Conner 1991; Grant 1996; Nelson and Winter 1982; Simon 1991; Weick and Roberts 1993).

Previous studies on organizational learning, particularly those that are empirically based, have tilted toward learning from aggregate organizational experience, with the implicit but not explicit implication that organizational learning arises from success generally (e.g., Darr et al. 1995; Ingram and Baum 1997). However, later studies began to analyze learning from prior failure that are separate from general experience (Haunschild and Sullivan 2002; Miner et al. 1999). This thinking was rooted in the behavioral theory of the firm (Cyert and March 1963) with its 
emphasis on decision-makers' interpretation of experiences as representing organizational knowledge.

Even though prior successful experience may not prevent decision-makers from learning, it is likely to discourage 'non-local search' (March 1981), a situation that can be worsened by the decision makers' overconfidence (Louis and Sutton 1991). However, prior failure can lead to the adoption of new and diverse ideas that are unlikely to be revealed in other forms of organizational search; hence, this 'problemistic search' can be the response from urgency of an organization (March 1981). This prior failure connotes both the existing gap and where the gap exists in organizational learning (Wildavsky 1988). Hence, learning from failure drives "the motivation to alter knowledge" and the capability to absorb significant knowledge from failure experience (Levinthal and March 1981).

Unfortunately, in the management field, there have been very few studies on learning from failure, and, consequently, it has not been combined with or compared to learning from success directly and/or empirically, despite researchers in this field arguing the meaningfulness of such studies (Deichmann and Van den Ende 2014; Desai 2015; Khanna et al. 2016; Madsen and Desai 2010; Maslach 2016; Muehlfeld et al. 2012). In this vein, Madsen and Desai (2010, p. 451) claimed that "it is unclear whether the common finding of improved organizational performance with increasing organizational experience is driven by learning from success, learning from failure, or some combination of the two." Indeed, organizational learning can be truly occurred when an organization's certain operations or projects actually failed, ${ }^{2}$ and based on the 'problemistic search' from its failure, that organization can learn more from failure than success (e.g., Cyert and March 1963; March and Shapira 1992). It is because learning from failure than learning from success provides an organization to greater opportunities to learn (Sitkin 1992).

Moreover, organizational learning does not only occur from an organization's direct experience, but also from other organizations' experience; the process known as 'vicarious learning' (Beckman and Haunschild 2002; Denrell 2003; Ingram and Baum 1997; Jiang et al. 2014; Jiménez and De la Fuente 2016; Kim and Miner 2007; Madsen and Desai 2010; Srinivasan et al. 2007). Even in the case of vicarious learning, vicarious learning from failure has a stronger impact on overall learning than vicarious learning from success. This is true for two reasons. First, building on the assumption that direct learning from success and failure has a similar learning mechanism with vicarious learning from success and failure, decision-makers may be overconfident about others' success experience leading them that to avoid intensive search activities (Wildavsky 1988). However, these decision-makers think others' failure experience is critical for the benchmarking from others' failure experience, so they can question their own experiential knowledge; thus, it instigates intensive 'problemistic search' (Baum and Dahlin 2007). Second, decision-makers

\footnotetext{
${ }^{2}$ In this paper, an organization's failure means not only the organization's certain operations or projects having failed, but also the organization itself being divested. Besides, learning can also happen when other firms divest (vicarious learning).
} 
think their success needs to be tightly protected by secrecy, as it becomes effectively private information to be held confidentially (Arundel 2001; Katila et al. 2008). Yet, failure tends to be open and public not only by the organizational members (Kim and Miner 2007) but also by social media.

In line with Madsen and Desai (2010)'s study and the above discussion, Deichmann and Van den Ende (2014. p. 670) empirically explored how the success and failure experiences affect "(a) the inclination to take new...initiatives and (b) the outcome of those initiatives" by emphasizing "the role of past experience in radical initiative taking" on "rising from failure and learning from success." Their findings are in line with the notion that failure can instigate more learning than success does in the vein of "learning to improve" (Shepherd and Cardon 2009). Based on 4973 acquisition trials in the newspaper industry, Muehlfeld et al. (2012, p. 938) empirically explored the question of "whether learning from experience gained in different acquisition contexts is limited to influencing subsequent outcomes of same-context transactions", and "whether learning patterns in response to prior successes and failures differ across acquisition contexts, depending on two properties of these contexts the degree of structural variance and the level of stimulation of deliberate learning."

In a similar context, Maslach (2016, p. 714) found that organizations "change innovation activities when novel innovations fail, but persist when incremental innovations fail"; supporting the notion that failure from incremental innovations is likely to motivate organizations to be more willing to keep a persistence when failure happens. As an extension of studies on learning from failure, Desai (2015, p. 1032) argued that "organizations learn less effectively when their failures are relatively concentrated in origin, meaning that failures typically involve a particular unit...compared to when failures are more broadly dispersed." On the other hand, Khanna et al. (2016, p. 436) investigated "whether and under what circumstances firms learn from their small failures in experimentation" and "the conditions under which prior failures influence firms' $R \& D$ output, in terms of amount and quality. In this context, Khanna et al. (2016) emphasized 'trial-and-error learning' and 'experimentation' when firm learn from failure. In a similar vein, in the context of innovation, the learning timing is a crucial component of experiential learning. In particular, the timing for learning from failure is critical since rapid feedback can enhance faster learning and elimination of incorrect selections (Eggers 2012; Sitkin 1992; Skinner 1954), while delayed learning can cause serious 'noise' (Denrell et al. 2004; Kettle and Häubl 2010).

In sum, we have to see the broader scope of organizational learning including the comparison between learning from success versus failure, and this gap should be considered not only by the studies in the management field, but also by the studies in the domain of IB. In this vein, the next section of learning from success versus failure in SME internationalization can be suggested a meaningful extension from the literature in management, as well as a significant contribution to the literature in IB. 


\subsection{Learning from Failure: Bibliographic Evidence}

Similar to the previous section, we conducted a historical search of the literature on learning from failure. The results are revealed in Table $2 .^{3}$

In 1998 the first paper (Ariño and De la Torre 1998) on this topic, entitled "Learning from failure: Towards an evolutionary model of collaborative ventures", was published in "Organization Science (OS)". Ariño and De la Torre (1998, p. 306) explored "the interaction between two partners to a failed international joint venture" by developing "a model of the collaboration process in partnership and alliances" grounded in the previous studies (i.e., Doz 1996; Ring and Van de Ven 1994). Ariño and De la Torre's (1998, p. 307) conception of learning from failure is in the context of alliance failure, which is attributed to "initial conditions that are inconsistent with economic efficiency requirements or which hamper learning" from alliance failure.

Following on from this work we see a dearth of publications until 2003 Chuang and Baum (2003) publish their study, entitled "It's all in the name: Failure-induced learning by multiunit chains", in the "Administrative Science Quarterly". Chuang and Baum (2003, p. 33) explored "the effects of component failures on naming strategies" by advancing "organizational and interorganizational learning processes to explain (multiunit) chains' adoption of local naming strategies" as focusing "on learning from failure of strategy...from their analysis of nursing home chains' naming strategies". The next year, Haunschild and Rhee (2004, p. 1545) argued that "volition is important for (organizational) learning because autonomy increases commitment and problem analyses", but "mandate is (also) important for learning because external pressures act as jolts that help overcome organizational inertia, resulting in deep exploration of problems" by following "the learning-curve tradition in investigating the effects of voluntary and involuntary recalls on subsequent recall rates".

After 3 years since Haunschild and Rhee (2004) claimed the role of volition in organizational learning in the case of automotive product recalls, Kim and Miner (2007, p. 687) researched if organizations vicariously learn from failures and nearfailures of others" with a sample of the US commercial banking industry, and found that "[b]ank near-failure experience had more value than bank failure experience, but thrift failure and near-failure experience had equivalent impact(s), suggesting that the learning impact of types of failure-related experience varies with its industry origin".

Kim et al. (2009, p. 958), were the next major authors taking on the subject by exploring two different types of a firm's own extreme performance experiences, i.e., success and recovery (often representing valuable sources of useful learning), and their interaction can generate survival-enhancing learning. By defining "recovery experience" as "a type of failure experience ... as occurring when a firm experiences extremely poor performance but later overcomes it", Kim et al. (2009, p. 958) argued that success and recovery experiences "can help learning challenges such

\footnotetext{
${ }^{3}$ See the method and details of this literature search is in Appendix 2.
} 


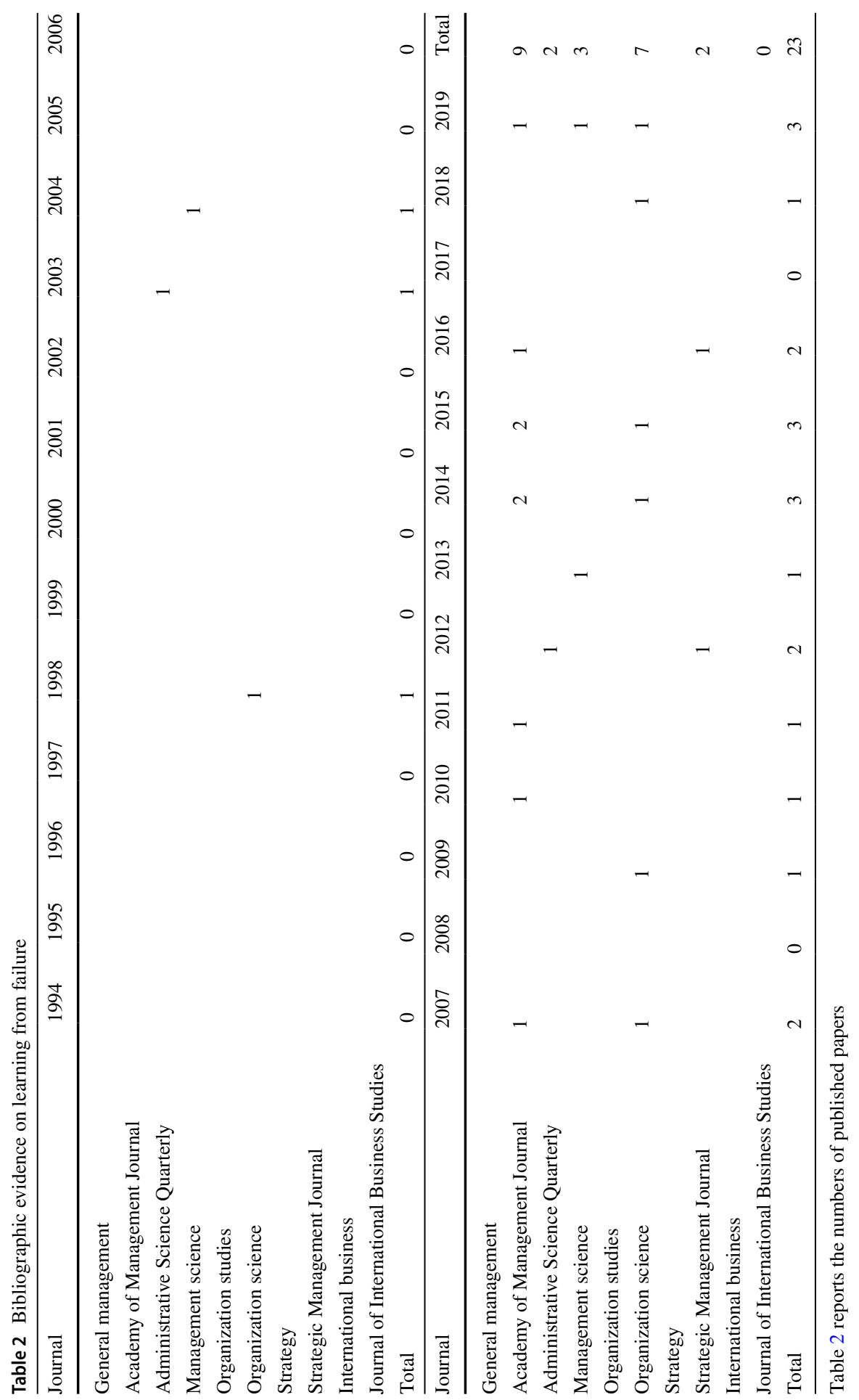


as superstitious learning or learning from small samples" based on a sample of the US commercial banks. The next year, Madsen and Desai (2010, p. 451) found that "organizations learn more effectively from failures than successes, that knowledge from failure depreciates more slowly than knowledge from success, and that prior stocks of experience and the magnitude of failure influence how effectively organizations can learn from various forms of experience" with a sample of the orbital launch vehicle industry.

In 2011, Shepherd et al. "conjointly consider(ed) learning from failure and affective commitment to an organization" as determining how organizational members "move forward from project failure" by learning from failure (p. 1229). Then, in 2012, Muehlfeld et al. explored "[a] contextual theory of organizational learning from failure and success" in terms of "the context-specificity and outcome-dependence of experiential learning in acquisition processes" based on a sample of acquisition attempts in the global newspaper industry.

The last decade has seen a reasonable stream of publications on learning from failure. Nevertheless, this has not been the case in the IB field. No papers were published on the topic in the "Journal of International Business Studies" from 1994 to 2019. This implies that there is a gap in the IB research on learning from failure or on the comparison between learning from success and learning from failure, despite the fact that exporters and MNEs have often failed and learned from those failures. IB researchers need to fill this vacuum since, just like the general organizations, 'problemistic search' from its failure (Cyert and March 1963; March and Shapira 1992) is crucial for the learning mechanism for these internationalized organizations (cf., Cyert and March 1963; March and Shapira 1992).

\section{Learning from Success versus Failure in SME Internationalization}

As previously mentioned, there have been relatively few studies on the topic of learning from failure or the comparison between learning from success and learning from failure. This is particularly pronounced in the IB literature, despite the critical role of learning from failure for internationalization. If we take one step further, we may explain the linkage between learning in SME internationalization and learning from failure based on two reasons. First, 'experimentation and trial-and-error learning' (Khanna et al. 2016) are more likely to occur in entrepreneurial firms rather than large firms, and in this paper, we deal with SME cases so that 'problemistic search' from SMEs' failures is more contextually matching. Second, although the original and the updated Uppsala models emphasized knowledge and learning in the internationalization process, their assumption of (market and internationalization or relationship-specific) knowledge and learning is implicitly based on an aggregated concept of general (market and internationalization or relationship) knowledge or experience; thus this learning in the internationalization process tends to rely on general knowledge-based learning whether it comes to self-knowledge or relationship-specific knowledge. Further, after our critical review of the existing studies, particularly empirical ones, based on Johanson and Vahlne's (1977) and (2009) model, by have verified that their research focus has been on success or successful 
experience due to (1) their conceptual limitation of "successive incremental commitment to foreign markets" and (2) the limitedness of data accessibility to failed foreign direct investment (FDI) or failed exporting. Also, Knight and Cavusgil's (2004) born global firm framework is to some extent limited since their view also connotes aggregated general knowledge or learning or more critically their perspective also implicated success cases for born global firms in the early and rapid internationalization rather than failure cases for them.

Within this context, how can we integrate learning in SME internationalization with learning from failure or comparison between learning from success and learning from failure as a new comprehensive framework? As SMEs do not have breadth of experience, learning is more salient, and they cannot fail many times. Hence, failure must be followed by success, especially in the case of SMEs. For SMEs, understanding failure is much more critical than in large enterprises, as is the need to ensure that failure is followed by success. Under the circumstances, it is crucial for IB scholars and practitioners to be able to understand learning from success and failure in SME internationalization. However, this important integration has never happened in any paper in any sector and discipline, so we fill this gap in the existing literature in the fields of both IB and management. First, in Fig. 2, we provide an integration Johanson and Vahlne's (1977) and (2009) models with Kirzner's (1973) conception of entrepreneurship. Second, we refine an integrative framework between learning in SME internationalization and self- and vicarious learning from success versus failure in Fig. 3.

Figure 2 depicts Johanson and Vahlne's 1977 and (2009) models. We include the core discussions and concepts from Johanson and Vahlne's (1977) and (2009) models. As it can be seen in the bottom of Fig. 2. Time $(t)$ means that, based on 'psychic distance', the three stages of internationalization process moves from exporting and 'selling via agents' at stage one, the establishment of sales subsidiaries and "acquisition of the former agents or organizing around some person employed by the agent" at stage two, and lastly the establishment of manufacturing subsidiaries via acquisition or greenfield investment at stage three. This is the one of the core components in the Uppsala model. Also, we illustrate Johanson and Vahlne's (2009) combination of Kirzner's (1973) concept of entrepreneurship with business network perspective with an emphasis of the firm's incremental commitment on general relationship knowledge and learning in the internationalization process, which was extended from their incremental commitment on general market and internationalization knowledge and learning in the internationalization process in the original 1977 model.

As can be seen in Fig. 2, knowledge and learning as conceptualized in the 1977 and 2009 Uppsala models are based on absorptive capacity (Cohen and Levinthal 1990), evolutionary theory (Nelson and Winter 1982), a 'learning-cycle' model (Forsgren 2002; Levitt and March 1988), and 'learning curves' (Argote 1999). So, in the Uppsala model, knowledge and learning are directly related to organizational learning perspective. Therefore, Fig. 2 presents a coherent perspective that integrates the 1977 and 2009 Uppsala models, Kirzner's entrepreneurship concept, and organizational learning theory. In this way, the readers can easily understand the core thrusts of these two versions of the Uppsala model. 


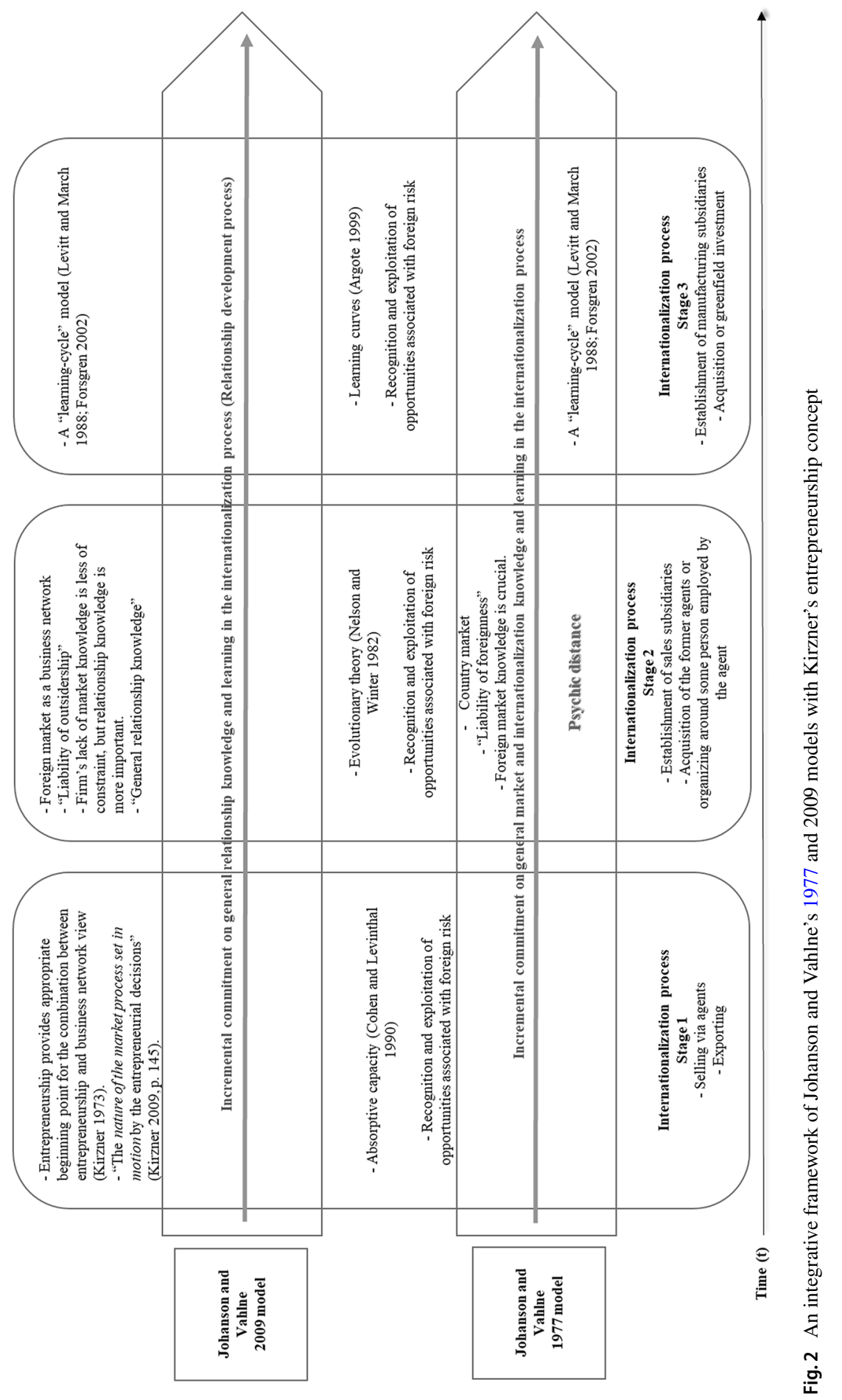




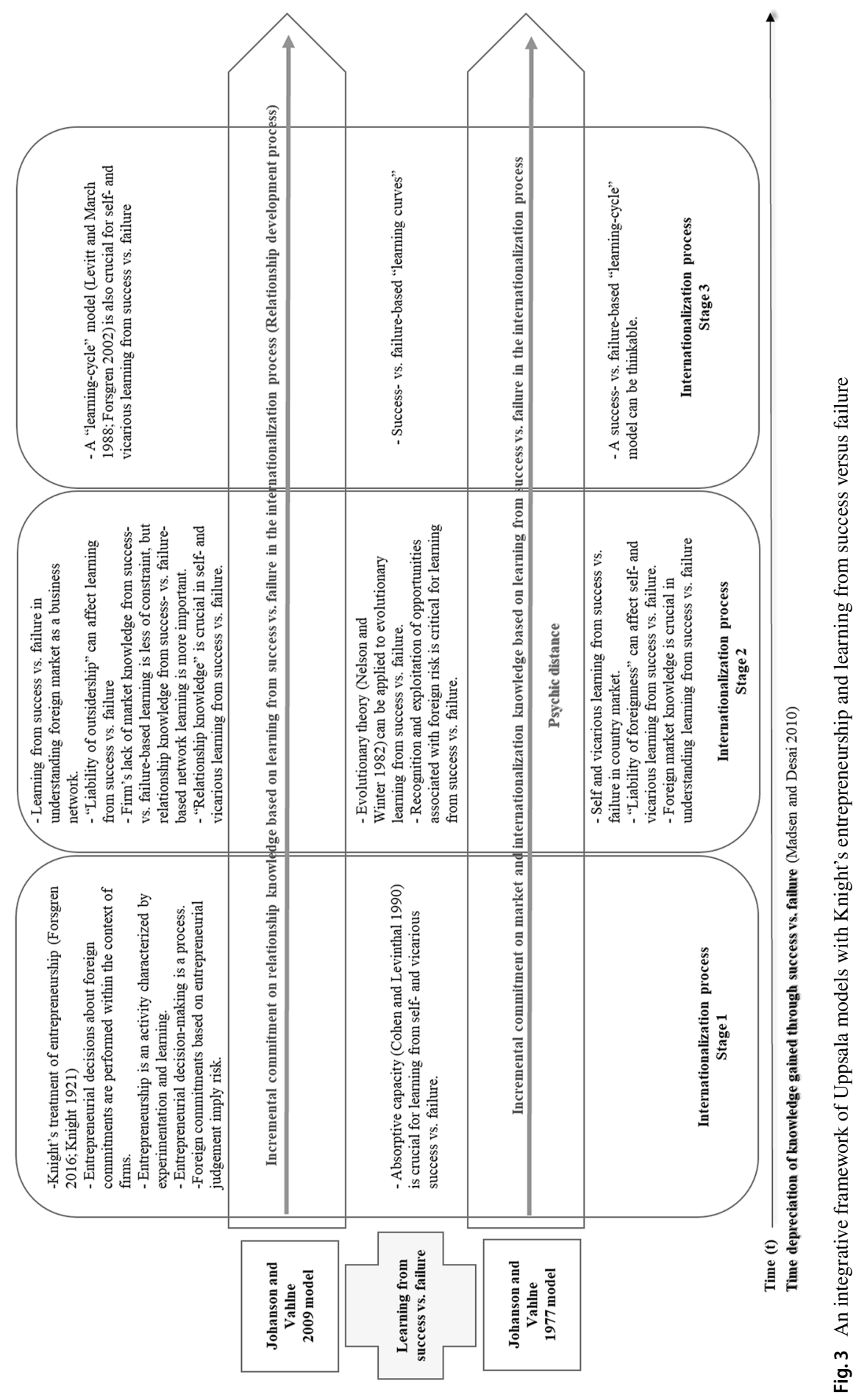


Figure 3 shows the integrative framework combining Johanson and Vahlne's (1977) and (2009) models with learning from success versus failure (Deichmann and Van den Ende 2014; Desai 2015; Khanna et al. 2016; Madsen and Desai 2010; Maslach 2016; Muehlfeld et al. 2012). Also, following the suggestion from Forsgren (2016), we integrate 'Knight's treatment of entrepreneurship' (1921), since Knight's perspective of entrepreneurship is more appropriate to explain 2009 Uppsala model than Kirzner's (1973).

In Fig. 3, we, first, underline the self and vicarious learning from success versus learning failure in the internationalization process. This addressed that the 'liability of foreignness' and 'liability of outsidership' can affect self- and vicarious learning from success versus failure due to their detrimental effects on the fates of internationalized organizations. Something that is of particular importance to SMEs, which suffer from resource constraints and a 'liability of newness'. Second, internationalized firms' lack of market knowledge from success- versus failure-based learning is less of a constraint since they can absorb this type of market knowledge more easily than 'relationship knowledge' from success- versus failure-based network learning. In particular, internationalized SMEs might find it difficult to obtain knowledge from success- versus failure-based network learning due to their more limited international networking compared to large multinationals. In addition, born global firms or international small ventures are characterized by early and rapid internationalization as their key to success is 'asset parsimony' (Cavugil and Knight 2015), their obtaining of the valuable relationship knowledge from success- versus failurebased network learning can ramp up their relatively small scale and limited tangible resources and capabilities.

In Fig. 3, we also emphasize the interrelations between absorptive capacity (Cohen and Levinthal 1990), evolutionary theory (Nelson and Winter 1982) and learning curves (Argote 1999), with success- versus failure-based learning, offering a comprehensive picture of how self- and vicarious success- versus failure-based learning combine with the organizational learning theory and its constructs.

\section{Review on Focused Issue Papers}

In this focused issue we aim to present theoretical and empirical evidence that extend our understanding on the interplay between SME internationalization and learning from success and failure. In response to the call of paper distributed in 2018, we received 20 formal submissions, as well as some additional informal ones from researchers whose projects were not encouraged to be submitted because they did not align well with the goals of the focused issue. We are grateful to the many anonymous reviewers who helped us during the review process and whose comments significantly improved the manuscripts. After the peer-review process, we selected five articles that we believe address important issues related to the topic of SME internationalization and learning from success and failure. We introduce these selected papers next.

Linking these papers to Figs. 2 and 3, three out of these five papers deal with how SMEs' information exchange and interorganizational learning in global value 
chains affect the maintaining of innovation levels and competitiveness in Thai SME internationalization (Soontornthum et al. 2020), how the breadth and depth of international network searching and learning intent affect Chinese SMEs' exploratory learning (Xiao et al. 2020), and how Indian SMEs' success- and failure-based learning affects post-internationalization growth and survival with the emphasis of vicarious, congenital and experiential learning (Puthusserry et al. 2020). These three papers are directly in line with 'relationship knowledge' and 'business network perspective', as well as entrepreneurship and learning in internationalization process in the 1977 and 2009 Uppsala models and our integration of self- and vicarious learning from success and failure with Uppsala models (see Figs. 2 and 3). For example, Puthusserry et al. (2020) found self- and vicarious learning from success and failure (trial-and-error experience) based on SMEs in India, which matches our illustration of criticality of these types of learning from success and failure in SME internationalization process in Fig. 3.

The other two papers place more weight on entrepreneurship and business network perspective as emphasized by the 2009 Uppsala model (see Fig. 2). Gerschewski et al. (2020) highlight the role of trade shows and their importance as a source of links and connections to allow Australian and New Zealand SMEs to create networks in these SMEs' internationalization, while Menzies et al. (2020) point out that weak relational and structural social capital is found to provide network resources and information which affect entry mode of the internationalized Australian SMEs by comparing political and business social capital. The core thrusts of these two papers are in line with the 2009 Uppsala model, which combined Kirzner's (1973) concept of entrepreneurship with the business network view in Fig. 2 and Knight's (1921) treatment of entrepreneurship with the business network view in Fig. 3 that international networking is crucial in SME internationalization process and SME international commitment needs to be performed within these contexts of entrepreneurial decision-making.

Table 3 shows the summary of the five papers included in this focused issue.

\section{Conclusion}

In Vahlne's latest paper (2020, p. 239), he summarizes the "[d]evelopment of the Uppsala model of internationalization process" and argues more recently that the Uppsala model's discussions have been changed from internationalization process to "other dimensions in firms' evolution, such as R\&D, and organizational and strategic change processes...to follow similar processes of learning and commitments". In addition, he suggests three future research avenues in relation to the Uppsala models: (1) a study of "the micro-foundations of global strategy", (2) an analysis of "evolutionary processes", and (3) a study of "strategy development in an MBE (Multinational Business Enterprise)" (Vahlne 2020, p. 246). All of these further applications for the Uppsala models, suggested by Vahlne, may apply to our integrative model between the Uppsala models and learning from success and failure. First, as organizational (firm-level) learning from success and failure is originated from an organizational member (individual) level, we can apply the micro-foundations of 


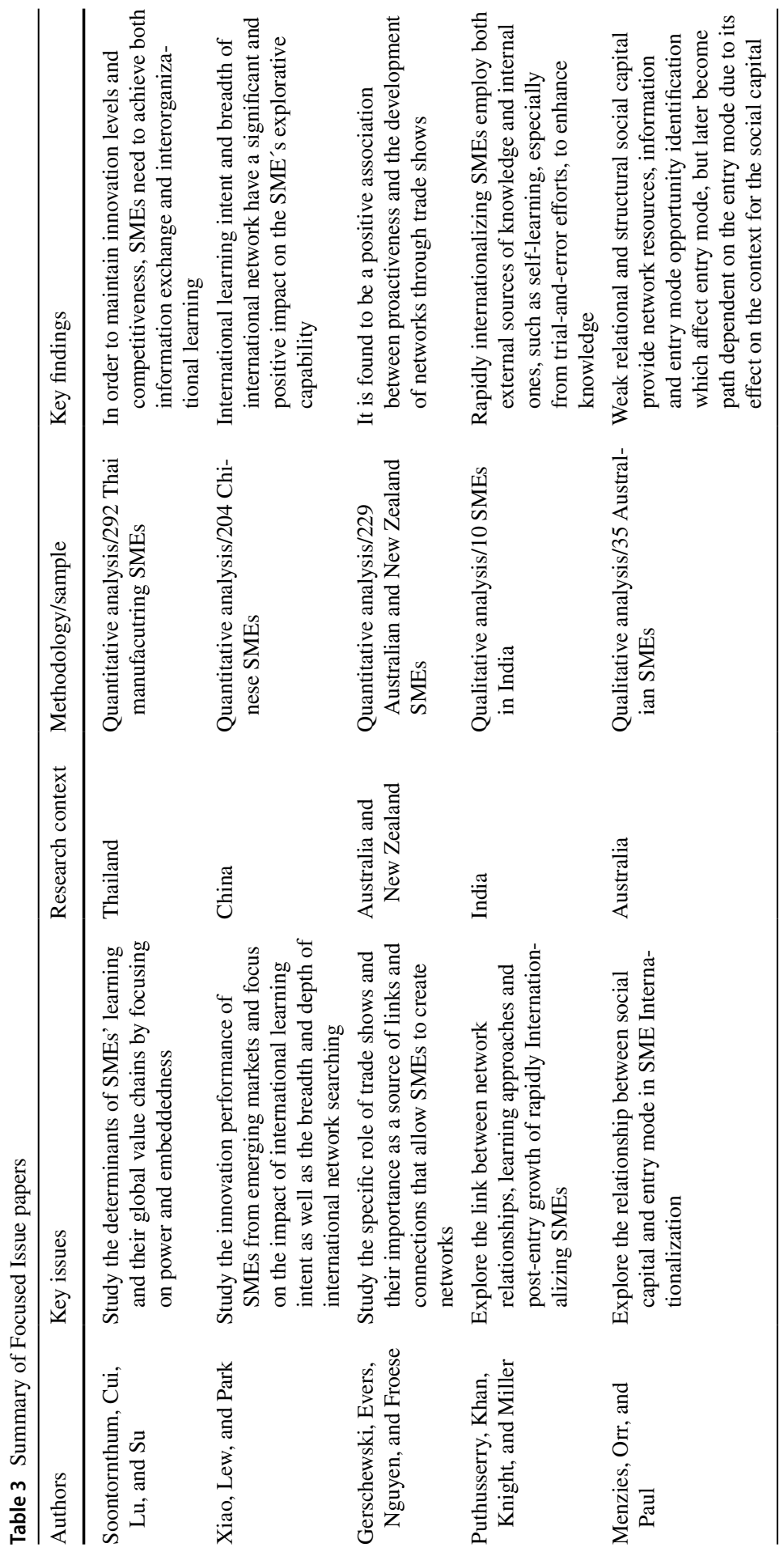


global strategy, such as psychological findings, just like Vahlne's (2020) vision of the future Uppsala model, on our integrative model. Second, because organizational learning from success and failure is an evolutionary process (Nelson and Winter 1982), it is possible to integrate Vahlne's (2020) future vision of the Uppsala model with our own integrative model. Third, studying the development of strategy in multinationals is closely linked to the connection between 'strategy content and process research', which are also important for organizational learning from success and failure since 'the process can help explain the strategy content' in the learning mechanism. Therefore, as Vahlne claims (2020, p. 247), "an interchange between knowledge development and commitments and process" is open-ended and never stops.

In sum, the goal of this focused issue has been to enlarge our knowledge of the relatively unexplored interplay between SME internationalization and learning from success versus failure. In this paper, we have reviewed and combined both streams of the literature and find that, despite its theoretical interest and managerial relevance, the IB field has largely neglected this topic. We then introduce five articles that compose this focused issue and that, collectively, extend the literature on SME's learning and internationalization, providing insightful theoretical and managerial contributions. Yet, we believe that additional efforts should be undertaken to expand our understanding and thus encourage researchers to conduct both theoretical and empirical studies to explore this fascinating topic.

Acknowledgements We are particularly indebted to the anonymous reviewers who assisted us during the peer-review process and whose comments improve the papers of this focused issue in a very significant way. We are also grateful to the Editors-in-Chief of MIR, Dr. Wolf and Dr. Oesterle. Finally, we are grateful to Chongqing Technology and Business University for their generosity during the organization of the focused issue workshop during the summer of 2019.

\section{Appendix 1}

In order to look at the recent trend of publications for learning in SME internationalization, we reviewed the prior studies based on the methodology similar to that used by Sedziniauskiene et al. (2019). As a result of our literature review, we found 159 papers published and available in-press during the period of 1994 through 2019 for 26 years after 10 journals in the fields of strategy, IB, and entrepreneurship/small business management. The search was performed between January and February of 2020 based on the guidelines of Denyer and Tranfield (2009) and Nolan and Garavan (2016). Based on these guidelines, we formulate the keywords string that was - (Learning* OR knowledge* OR experience*) AND (internationalization*) AND (SME* OR new venture* OR born global* OR global start*up* OR entrepreneurial*). We utilized three databases, i.e., Web of Science, Science Direct, and Google Scholar since these databases can cover rich sources with reserved accuracy. We also chose a paper type as double-blind reviewed journal papers, and, following Ordanini et al. (2008), no 'gray literature' was included. The list of journals was based on both journals' topic coverages and rankings based on the Association of Business Schools (ABS) (Sedziniauskiene et al. 2019). The journals in the sample belong to the fields of strategy, IB, and entrepreneurship and small business management, as 
classified by the ABS ranking. For the period of search, we considered when was the first time that the scholar(s) published meaningful attempts to understand learning in SME internationalization process, but we also include three previous years from this beginning of the publication of this meaningful attempt because we would like to show there had been no publication before that time. Following the literature (Sedziniauskiene et al. 2019), we analyzed not only empirical papers, but also conceptual and theoretical papers.

\section{Appendix 2}

In order to look at the recent trend of publications for learning from failure, as we did in Sect. 4, we reviewed the prior studies based on a similar methodology as the one used by Sedziniauskiene et al. (2019). As a result of our literature review, we found 23 papers published and available in-press during the period of 1994 through 2019 for 26 years after six journals in the fields of general management, organization studies, strategy, and international business. The search was performed in January and February of 2020 based on the guidelines of Denyer and Tranfield (2009) and Nolan and Garavan (2016). Accordingly, we formulate the keywords string that was - (Learning* OR knowledge* OR experience*) AND (failure*) AND (organization* OR firm* OR company* OR enterprise* OR corporation* OR bank* OR hospital* OR multinational*). We utilized three databases, i.e., Web of Science, Science Direct, and Google Scholar and chose a paper type as double-blind reviewed journal papers. The list of journals was based on both journals' topic coverages and rankings (Sedziniauskiene et al. 2019) based on the leading business journal's list of the University of Texas at Dallas 24 (UTD24). For the period of search, we considered when was the first time that the scholar(s) published meaningful attempts in the fields of general management, organization studies, strategy, and IB to understand learning from failure importantly, but we also include four previous years from this beginning of the publication of this meaningful attempt because we would like to show there had been no publication before that time. Following the literature (Sedziniauskiene et al. 2019), as we did in Sect. 4, we analyzed not only empirical papers, but also conceptual and theoretical papers.

\section{References}

Argote, L. (1999). Organizational learning: Creating, retaining and transferring knowledge. London: Kluwer Academic Publishers.

Ariño, A., \& De la Torre, J. (1998). Learning from failure: Towards an evolutionary model of collaborative ventures. Organization Science, 9(3), 306-325.

Arundel, A. (2001). The relative effectiveness of patents and secrecy for appropriation. Research Policy, 30(4), 611-624.

Axelsson, B., \& Johanson, J. (1992). Foreign market entry: The textbook vs the network view. In B. Axelsson \& G. Easton (Eds.), Industrial networks: A new view of reality (pp. 218-231). London: Routledge.

Barkema, H. G., Bell, J. H. J., \& Pennings, J. M. (1996). Foreign entry, cultural barriers, and learning. Strategic Management Journal, 17(2), 151-166. 
Barkema, H. G., \& Vermeulen, F. (1998). International expansion through start-up or acquisition: A learning perspective. Academy of Management Journal, 41(1), 7-26.

Baum, J. A., \& Dahlin, K. B. (2007). Aspiration performance and railroads' patterns of learning from train wrecks and crashes. Organization Science, 18(3), 368-385.

Beck, N., Brüderl, J., \& Woywode, M. (2008). Momentum or deceleration? Theoretical and methodological reflections on the analysis of organizational change. Academy of Management Journal, 51(3), 413-435.

Beckman, C., \& Haunschild, P. (2002). Network learning: The effects of partners heterogeneity of experience on corporate acquisitions. Administrative Science Quarterly, 47(1), 92-124.

Bingham, C. B., \& Davis, J. P. (2012). Learning sequences: Their existence, effect, and evolution. Academy of Management Journal, 55(3), 611-641.

Bingham, C. B., \& Haleblian, J. J. (2012). How firms learn heuristics: Uncovering missing components of organizational learning. Strategic Entrepreneurship Journal, 6(2), 152-177.

Blankenburg Holm, D., Johanson, M., \& Kao, T. P. (2015). From outsider to insider: Opportunity development in foreign networks. Journal of International Entrepreneurship, 13(3), 337-359.

Bruneel, J., Yli-Renko, H., \& Clarysse, B. (2010). Learning from experience and learning from others: How congenital and interorganizational learning substitute for experiential learning in young firm internationalization. Strategic Entrepreneurship Journal, 4(2), 164-182.

Casillas, J. C., Barbero, J. L., \& Sapienza, H. J. (2015). Knowledge acquisition, learning, and the initial pace of internationalization. International Business Review, 24(1), 102-114.

Casillas, J. C., \& Moreno-Menendez, A. M. (2014). Speed of the internationalization process: The role of diversity and depth in experiential learning. Journal of International Business Studies, 45(1), $85-101$.

Cavusgil, S. T., \& Knight, G. (2009). Born global firms: A new international enterprise. New York: Business Expert Press.

Cavusgil, S. T., \& Knight, G. (2015). The born global firm: An entrepreneurial and capabilities perspective on early and rapid internationalization. Journal of International Business Studies, 46(1), 3-16.

Chang, S. J. (1995). International expansion strategy of Japanese firms: Capability building through sequential entry. Academy of Management Journal, 38(2), 383-407.

Chetty, S., \& Campbell-Hunt, C. (2003). Explosive international growth and problems of success amongst small to mediumsized firms. International Small Business Journal, 21(1), 5-27.

Chuang, Y.-T., \& Baum, J. A. C. (2003). It's all in the name: Failure-induced learning by multiunit chains. Administrative Science Quarterly, 48(1), 33-59.

Cohen, W. M., \& Levinthal, D. A. (1990). Absorptive capacity: A new perspective on learning and innovation. Administrative Science Quarterly, 35(2), 128-152.

Conner, K. R. (1991). A historical comparison of resource based theory and five schools of thought within industrial organization economics: Do we have a new theory of the firm? Journal of Management, 17(1), 121-154.

Coviello, N. (2015). Re-thinking research on born globals. Journal of International Business Studies, 46(1), 17-26.

Coviello, N., \& Munro, H. (1997). Network relationships and the internationalisation process of small software firms. International Business Review, 6(4), 361-386.

Cyert, R. M., \& March, J. G. (1963). A behavioral theory of the firm. Englewood Cliffs: Prentice Hall.

Darr, E., Argote, L., \& Epple, D. (1995). The acquisition, transfer, and depreciation of knowledge in service organizations: Productivity in franchises. Management Science, 41(11), 1750-1762.

De Clercq, D., Sapienza, H. J., Yavuz, R. I., \& Zhou, L. (2012). Learning and knowledge in early internationalization research: Past accomplishments and future directions. Journal of Business Venturing, 27(1), 143-165.

De Holan, P. M., \& Phillips, N. (2004). Remembrance of things past? The dynamics of organizational forgetting. Management Science, 50(11), 1603-1613.

Deichmann, D., \& Van den Ende, J. (2014). Rising from failure and learning from success: The role of past experience in radical initiative taking. Organization Science, 25(3), 670-690.

Deligianni, I., Voudouris, I., \& Lioukas, S. (2015). Growth paths of small technology firms: The effects of different knowledge types over time. Journal of World Business, 50(3), 491-504.

Deng, Z., Jean, R.-J. B., \& Sinkovics, R. R. (2018). Rapid expansion of international new ventures across institutional distance. Journal of International Business Studies, 49(8), 1010-1032.

Denrell, J. (2003). Vicarious learning, undersampling of failure, and the myths of management. Organization Science, 14(3), 227-243. 
Denrell, J., Fang, C., \& Levinthal, D. A. (2004). From T-mazes to labyrinths: Learning from model-based feedback. Management Science, 50(10), 1366-1378.

Denyer, D., \& Tranfield, D. (2009). Producing a systematic review. In D. A. Buchanan \& A. Bryman (Eds.), The SAGE handbook of organizational research methods (pp. 671-689). London: Sage Publications.

Desai, V. (2015). Learning through the distribution of failures within an organization: Evidence from heart bypass surgery performance. Academy of Management Journal, 58(4), 1032-1050.

Doz, Y. (1996). The evolution of cooperation in strategic alliances: Initial conditions or learning processes? Strategic Management Journal, 17(S1), 55-84.

Eggers, J. P. (2012). All experience is not created equal: Learning, adapting, and focusing in product portfolio management. Strategic Management Journal, 33(3), 315-335.

Eisenhardt, K., \& Martin, J. (2000). Dynamic capabilities: What are they? Strategic Management Journal, 21(10-11), 1105-1121.

Erramilli, M. K. (1991). The experience factor in foreign market entry behavior of service firms. Journal of International Business Studies, 22(3), 479-501.

Eurofound. (2012). Born global: The potential of job creation in new international businesses. Luxembourg: Publications Office of the European Union.

Fletcher, M., \& Harris, S. (2012). Knowledge acquisition for the internationalization of the smaller firm: Content and sources. International Business Review, 21(4), 631-647.

Forsgren, M. (2002). The concept of learning in the Uppsala internationalization process model: A critical view. International Business Review, 11(3), 257-278.

Forsgren, M. (2016). A note on the revisited Uppsala internationalization process model the implications of business networks and entrepreneurship. Journal of International Business Studies, 47(9), 1135-1144.

Foss, N. J., \& Klein, P. (2012). Organizing entrepreneurial judgement: A new approach to the firm. Cambridge: Cambridge University Press.

Gabrielsson, M., \& Kirpalani, V. H. M. (2004). Born globals: How to reach new business space rapidly. International Business Review, 13(5), 555-571.

Gabrielsson, M., Kirpalani, V., \& Dimitratos, P. (2008). Born globals: Propositions to help advance the theory. International Business Review, 17(4), 385-401.

Gerschewski, S., Evers, N., Nguyen, A., \& Froese, F. J. (2020). Trade shows and SME internationalisation: Networking for performance. Management International Review, 60(4). https://doi. org/10.1007/s11575-020-00421-y.

Grant, R. M. (1996). Toward a knowledge-based theory of the firm. Strategic Management Journal, 17(2), 109-122.

Gupta, U. (1989). Small firms aren't waiting to grow up to go global. Wall Street Journal.

Haunschild, P. R., \& Rhee, M. (2004). The role of volition in organizational learning: The case of automotive product recalls. Management Science, 50(11), 1545-1560.

Haunschild, P. R., \& Sullivan, B. N. (2002). Learning from complexity: Effects of prior accidents and incidents on airlines' learning. Administrative Science Quarterly, 47(4), 609-643.

Hoang, H., \& Rothaermel, F. T. (2005). The effect of general and partner-specific alliance experience on joint R\&D project performance. Academy of Management Journal, 48(2), 332-345.

Huber, G. P. (1991). Organizational learning: The contributing processes and the literatures. Organization Science, 2(1), 88-115.

Ingram, P., \& Baum, J. A. (1997). Chain affiliation and the failure of Manhattan hotels, 1898-1980. Administrative Science Quarterly, 42(1), 68-102.

Jiang, G. F., Holburn, G. L., \& Beamish, P. W. (2014). The impact of vicarious experience on foreign location strategy. Journal of International Management, 20(3), 345-358.

Jiménez, A., \& De la Fuente, D. (2016). Learning from others: The impact of vicarious experience on the psychic distance and FDI relationship. Management International Review, 56(5), 633-664.

Johanson, J., \& Vahlne, J.-E. (1977). The internationalization process of the firm: A model of knowledge development and increasing foreign market commitments. Journal of International Business Studies, 8(1), 23-32.

Johanson, J., \& Vahlne, J.-E. (1990). The mechanism of internationalisation. International Marketing Review, 7(4), 11-24.

Johanson, J., \& Vahlne, J.-E. (2003). Business relationship learning and commitment in the internationalization process. Journal of International Entrepreneurship, 1(1), 83-101. 
Johanson, J., \& Vahlne, J.-E. (2006). Commitment and opportunity development in the internationalization process: A note on the Uppsala internationalization process model. Management International Review, 46(2), 1-14.

Johanson, J., \& Vahlne, J.-E. (2009). The Uppsala internationalization process model revisited: From liability of foreignness to liability of outsidership. Journal of International Business Studies, 40(9), 1411-1431.

Jones, M. V., \& Coviello, N. E. (2005). Internationalization: Conceptualizing an entrepreneurial process of behavior in time. Journal of International Business Studies, 36(3), 284-303.

Katila, R., Rosenberger, J. D., \& Eisenhardt, K. M. (2008). Swimming with sharks: Technology ventures, defense mechanisms and corporate relationships. Administrative Science Quarterly, 53(2), $295-332$.

Kettle, K. L., \& Häubl, G. (2010). Motivation by anticipation: Expecting rapid feedback enhances performance. Psychological Science, 21(4), 545-547.

Khanna, R., Guler, I., \& Nerkar, A. (2016). Fail often, fail big, and fail fast? Learning from small failures and R\&D performance in the pharmaceutical industry. Academy of Management Journal, 59(2), 436-459.

Kim, J.-Y., Kim, J.-Y., \& Miner, A. S. (2009). Organizational learning from extreme performance experience: The impact of success and recovery experience. Organization Science, 20(6), 958-978.

Kim, J.-Y., \& Miner, A. S. (2007). Vicarious learning from the failures and near-failures of others: Evidence from the US commercial banking industry. Academy of Management Journal, 50(3), $687-714$.

Kirzner, I. (1973). Competition and entrepreneurship. Chicago: University of Chicago Press.

Kirzner, I. (1978). Competition and entrepreneurship (2nd ed.). Chicago: University of Chicago Press.

Kirzner, I. M. (2009). Mises and his understanding of the capitalist system. Cato Journal, 19(2), 215-232.

Kiss, A., Danis, W., \& Cavusgil, S. T. (2012). International entrepreneurship research in emerging economies: A critical review and research agenda. Journal of Business Venturing, 27(2), 266-290.

Knight, F. H. (1921). Risk, uncertainty and profit. New York: August M. Kelly.

Knight, G. A., \& Cavusgil, S. T. (2004). Innovation, organizational capabilities, and the born-global firm. Journal of International Business Studies, 35(2), 124-141.

Knight, G. A., \& Kim, D. (2009). International business competence and the contemporary firm. Journal of International Business Studies, 40(2), 255-273.

Knight, G. A., \& Liesch, P. W. (2016). Internationalization: From incremental to born global. Journal of World Business, 51(1), 93-102.

Levinthal, D., \& March, J. G. (1981). A model of adaptive organizational search. Journal of Economic Behavior and Organization, 2(4), 307-333.

Levitt, B., \& March, J. G. (1988). Organizational learning. Annual Review of Sociology, 14, 319-340.

Li, L., Li, D., \& Dalgic, T. (2004). Internationalization process of small and medium-sized enterprises: Toward a hydrid model of experiential learning and planning. Management International Review, 44(1), 93-116.

Louis, M. R., \& Sutton, R. I. (1991). Switching cognitive gears: From habits of mind to active thinking. Human Relations, 44(1), 55-76.

Luo, Y., \& Peng, M. (1999). Learning to compete in a transition economy: Experience, environment and performance. Journal of International Business Studies, 30(2), 269-295.

Madsen, P. M., \& Desai, V. (2010). Failing to learn? The effects of failure and success on organizational learning in the global orbital launch vehicle industry. Academy of Management Journal, 53(3), $451-476$.

Madsen, T. K., \& Servais, P. (1997). The internationalization of Born Globals: An evolutionary process? International Business Review, 6(6), 561-583.

March, J. G. (1981). Footnotes to organizational change. Administrative Science Quarterly, 26(4), $563-577$.

March, J. G., \& Shapira, Z. (1992). Variable risk preferences and the focus of attention. Psychological Review, 99(1), 172-183.

Maslach, D. (2016). Change and persistence with failed technological innovation. Strategic Management Journal, 37(4), 714-723.

McDougall, P., \& Oviatt, B. (2000). International entrepreneurship: The intersection of two research paths. Academy of Management Journal, 43(5), 902-906. 
Menzies, J., Orr, S., \& Paul, J. (2020). SME internationalisation: The relationship between social capital and entry mode. Management International Review, 60(4). https://doi.org/10.1007/s11575-02000423-w.

Miller, D. (1998). The strategy reader. Hoboken: Blackwell Publishers.

Miner, A. S., Kim, J., Holzinger, I. W., \& Haunschild, P. (1999). Fruits of failure: Organizational failure and population-level learning. In A. S. Miner \& P. Anderson (Eds.), Advances in strategic management (pp. 187-220). Greenwich: JAI Press.

Minguzzi, A., \& Passaro, R. (2001). The network of relationships between the economic environment and the entrepreneurial culture in small firms. Journal of Business Venturing, 16(2), 181-207.

Monaghan, S., Tippmann, E., \& Coviello, N. (2020). Born digitals: Thoughts on their internationalization and a research agenda. Journal of International Business Studies, 51(1), 11-22.

Mort, G., \& Weerawardena, J. (2006). Networking capability and international entrepreneurship: How networks function in Australian born global firms. International Marketing Review, 23(5), 549-572.

Muehlfeld, K., Sahib, P. R., \& Van Witteloostuijn, A. (2012). A contextual theory of organizational learning from failures and successes: A study of acquisition completion in the global newspaper industry, 1981-2008. Strategic Management Journal, 33(8), 938-964.

Nadolska, A., \& Barkema, H. G. (2007). Learning to internationalise: The pace and success of foreign acquisitions. Journal of International Business Studies, 38(7), 1170-1186.

Nelson, R. R., \& Winter, S. G. (1982). An evolutionary theory of economic change. Cambridge: Belknap Press.

Nolan, C. T., \& Garavan, T. N. (2016). Human resource development in SMEs: A systematic review of the literature. International Journal of Management Reviews, 18(1), 85-107.

Oehme, M., \& Bort, S. (2015). SME internationalization modes in the German biotechnology industry: The influence of imitation, network position, and the international experience. Journal of International Business Studies, 46(6), 629-655.

Ordanini, A., Rubera, G., \& DeFillippi, R. (2008). The many moods of inter-organizational imitation: A critical review. International Journal of Management Reviews, 10(4), 375-398.

Oviatt, B., \& McDougall, P. (1994). Toward a theory of international new ventures. Journal of International Business Studies, 25(1), 45-64.

Padmanabhan, P., \& Cho, K. R. (1999). Decision specific experience in foreign ownership and establishment strategies: Evidence from Japanese firms. Journal of International Business Studies, 30(1), 25-44.

Pellegrino, J. M., \& McNaughton, R. B. (2015). The co-evolution of learning and internationalization strategy in international new ventures. Management International Review, 55(4), 457-483.

Petersen, B., Pedersen, T., \& Sharma, D. D. (2003). The role of knowledge in firms' internationalisation process: Wherefrom and whereto? In A. Blomstermo \& D. D. Sharma (Eds.), Learning in the internationalisation process of firms (pp. 36-55). Cheltenham: Edward Elgar.

Prashantham, S., Dhanaraj, C., \& Kumar, K. (2015). Ties that bind: Ethnic ties and new venture internationalization. Long Range Planning, 48(5), 317-333.

Presutti, M., Boari, C., \& Fratocchi, L. (2007). Knowledge acquisition and the foreign development of high-tech start-ups: A social capital approach. International Business Review, 16(1), 23-46.

Puthusserry, P., Khan, Z., Knight, G., \& Miller, K. (2020). How do rapidly internationalizing SMEs learn? Exploring the link between network relationships, learning approaches and post-entry growth of rapidly internationalizing SMEs from emerging markets. Management International Review, 60(4). https://doi.org/10.1007/s11575-020-00424-9.

Qian, G., Li, L., \& Qian, Z. (2018). Interactions among factors driving and inhibiting the early internationalization of small, young technology enterprises. Management International Review, 58(4), 251-280.

Rennie, M. (1993). Born global. McKinsey Quarterly, 4, 45-52.

Ring, P. S., \& Van de Ven, A. H. (1994). Developmental processes of cooperative interorganizational relationships. Academy of Management Review, 19(1), 90-118.

Santangelo, G. D., \& Meyer, K. E. (2011). Extending the internationalization process: Increases and decreases of MNE commitment in emerging economies. Journal of International Business Studies, 42(7), 894-909.

Sapienza, H. J., Autio, E., George, G., \& Zahra, S. A. (2006). A capabilities perspective on the effects of early internationalization on firm survival and growth. Academy of Management Review, 31(4), 914-933.

Schumpeter, J. A. (1934). The theory of economic development. Cambridge: Harvard University Press. 
Schweizer, R., Vahlne, J.-E., \& Johanson, J. (2010). Internationalization as an entrepreneurial process. Journal of International Entrepreneurship, 8(4), 343-370.

Schwens, C., \& Kabst, R. (2009). Early internationalization: A transaction cost economics and structural embeddedness perspective. Journal of International Entrepreneurship, 7(4), 323-340.

Sedziniauskiene, R., Sekliuckiene, J., \& Zucchella, A. (2019). Networks' impact on the entrepreneurial internationalization: A literature review and research agenda. Management International Review, 59(5), 779-823.

Shepherd, D. A., \& Cardon, M. S. (2009). Negative emotional reactions to project failure and the selfcompassion to learn from the experience. Journal of Management Studies, 46(6), 923-949.

Simon, H. (1991). Bounded rationality and organizational learning. Organization Science, 2(1), $125-134$.

Sitkin, S. B. (1992). Learning through failure: The strategy of small losses. Research in Organizational Behavior (pp. 231-266). Greenwich: JAI Press.

Skinner, B. F. (1954). The science of learning and the art of teaching. Harvard Educational Review, 24, 86-97.

Sleuwaegen, L., \& Onkelinx, J. (2014). International commitment, post-entry growth and survival of international new ventures. Journal of Business Venturing, 29(1), 106-120.

Smallbone, D., Welter, F., \& Ateljevic, J. (2014). Entrepreneurship in emerging market economies: Contemporary issues and perspectives. International Small Business Journal, 32(2), 113-116.

Soontornthum, T., Cui, L., Lu, V. N., \& Su, J. (2020). Enabling SMEs' learning from global value chains: Linking the logic of power and the logic of embeddedness of interfirm relations. Management International Review, 60(4). https://doi.org/10.1007/s11575-020-00425-8.

Srinivasan, R., Haunschild, P., \& Grewal, R. (2007). Vicarious learning in new product introductions in the early years of a converging market. Management Science, 53(1), 16-28.

Sui, S., \& Baum, M. (2014). Internationalization strategy, firm resources and the survival of SMEs in the export market. Journal of International Business Studies, 45(7), 821-841.

Sullivan-Mort, G., \& Weerawardena, J. (2006). Networking capability and international entrepreneurship: How networks function in Australian born global firms. International Marketing Review, 23(5), 549-572.

Tuomisalo, T., \& Leppäaho, T. (2019). Learning in international new ventures: A systematic review. International Business Review, 28(3), 463-481.

Vahlne, J.-E. (2020). Development of the Uppsala model of internationalization process: From internationalization to evolution. Global Strategy Journal, 10(2), 239-250.

Vahlne, J.-E., \& Johanson, J. (2013). The Uppsala model on evolution of the multinational business enterprise from internalization to coordination of networks. International Marketing Review, 30(3), $189-210$.

Weerawardena, J., Mort, G., Liesch, P., \& Knight, G. (2007). Conceptualizing accelerated internationalization in the born global firm: A dynamic capabilities perspective. Journal of World Business, 42(3), 294-306.

Weick, K. E., \& Roberts, K. H. (1993). Collective mind in organizations: Heedful interrelating on flight decks. Administrative Science Quarterly, 38(3), 357-381.

Wildavsky, A. (1988). Searching for safety. New Brunswick: Transaction Books.

Xiao, S. S., Lew, Y. K., \& Park, B. I. (2020). International network searching, learning, and explorative capability: Small and medium-sized enterprises from China. Management International Review, 60(4). https://doi.org/10.1007/s11575-020-00426-7.

Yeoh, P.-L. (2004). International learning: antecedents and performance implications among newly internationalizing companies in an exporting context. International Marketing Review, 21(4-5), 511-535.

Zahra, S., Ireland, R., \& Hitt, M. (2000). International expansion by new venture firms: International diversity, mode of market entry, technological learning, and performance. Academy of Management Journal, 43(5), 925-950.

Zhou, L., \& Wu, A. (2014). Earliness of internationalization and performance outcomes: Exploring the moderating effects of venture age and international commitment. Journal of World Business, 49(1), $132-142$.

Zhou, L., Wu, W., \& Luo, X. (2007). Internationalization and the performance of born global SMEs: The mediating role of social networks. Journal of International Business Studies, 38(4), 673-690.

Publisher's Note Springer Nature remains neutral with regard to jurisdictional claims in published maps and institutional affiliations. 